\title{
PUBLICATIONS OF THE ASSOCIATION.
}

\section{Journal of the Marine Biological Association. OLD Series.}

No. 1, Adgust, 1887 (only a few copies left, reserved for Libraries).

No. $\ddot{2}$, August, 1888. Price $1 s$.

New Series (Royal 8vo).

Volume'I., 1889-90, 472 pp., 28 plates.

Volume II., 1891-2, 410 pp., 14 plates.

Volume III., 1893-4, xxxviii. and 458 pp., 5 plates and 25 woodcuts.

Volume IV., 1895-7, iv. and $425 \mathrm{pp}$.

Volume V., 1897-9, 550 pp. and 16 plates.

Volume VI., 1899-1903, 676 pp., 3 charts and 7 plates.

Volume VII., 1904-6, 588 pp., 1 chart and 12 plates.

Volume VIII., Nos. 1, 2, and 3.

Separate numbers (generally 4 to one volume), in wrappers, from $2 s$. to $5 s$. each, according to size.

London Agents: Messrs. Dulau \& Co., 37 Soho Square, W.

Cloth 4to, 150 pp., 18 plates (12 coloured).

A TREATISE ON THE COMMON SOLE.

BX

J. T. CUNNINGHAM, M.A., F.R.S.E.,

Late Fellow of University College, Oxford; Naturalist to the Association.

Price to Members, 20s.; to Non-Members, $25 s$.

Medium 8vo, 368 pages. 159 Illustrations and two Maps. Price 7s. 6d. net.

(Macmillan \& Co., London.)

THE NATURAL HISTORY OF THE MARKETABLE

MARINE FISHES OF THE BRITISH ISLANDS.

Prepared expressly for the use of those interested in the Sea-fishing Industries,

BY

J. T, CUNNINGHAM, M.A.,

FORMERLY FELLOW OF UNIVERSITY COLLEGE, OXFORD;

NATURALIST ON THE STAFF OF THE MARINE BIOLOGICAL ASSOCIATION.

oratith Wreface by

E. RAY LANKESTER, M.A., LL.D., F.R.S.,

PROFESBOR OF COMPARATIVE ANATOMY IN THE UNIVERSITY OF OXFORD. 